\title{
THE EFFECT OF ANTILYMPHOCYTE SERUM ON SUBCUTANEOUS STAPHYLOCOCCAL INFECTIONS IN NORMAL, IMMUNE AND COMPLEMENT-DEFICIENT MICE
}

\author{
Fiona A. Medhurst, M. J. Hill and A. A. Glynn \\ Wright-Fleming Institute, St Mary's Hospital Medical School, London
}

DRUGS at present available for inhibiting the immune response are not specific for any one antigen but prevent responses to all antigens more or less equally. As a result, patients receiving immunosuppressive therapy are very liable to infection even by normally non-pathogenic organisms, and this is a major problem in transplanting organs.

The mode of action of antilymphocyte serum is still a matter for speculation, but is sufficiently different from that of earlier immunosuppressive agents to allow the hope that its use will be less liable to be complicated by infections. Published clinical experience (Kashiwagi et al., 1968) is so far encouraging.

We thought it would be worth investigating the effect of antilymphocyte serum on an experimental infection, and have chosen as our model one first described by Noble (1965) and characterised in detail by Agarwal (1967a, $b$ and $c$ ).

Standard doses of various strains of Staphylococcus aureus mixed with cotton dust were injected subcutaneously into mice to produce a local infection. The lesions were excised at intervals and their content of viable staphylococci was found by quantitative culture. The acute inflammatory response at $4 \mathrm{hr}$ was determined by injecting Evans blue intravenously and measuring the size of the subcutaneous blue zone round the cotton plug (Agarwal, 1967a). The size and severity of the lesion at 24 and $48 \mathrm{hr}$ was scored according to Noble's scheme, which is based largely on the area of skin necrosis over the lesion.

In normal mice, Agarwal (1967b) has shown that a "virulent" strain o Staph. aureus causes little or no oedema at $4 \mathrm{hr}$, multiplies from 100- to 10,000fold by $24 \mathrm{hr}$ and produces a severe purulent or necropurulent lesion. With " non-virulent" strains there is an early inflammatory response, slow multiplication of the bacteria and either a small final lesion or none at all.

We report the effect of the previous administration of antilymphocyte serum on subcutaneous staphylococcal infections in normal mice, in mice immunised with extracts of staphylococci (Hill, 1968), and in mice deficient in the fifth component of complement $\left(C^{\prime} 5\right)$. Bacterial multiplication, early oedema response and the final lesion were measured in all groups.

\section{MATERIALS AND METHODS \\ Production of lesions}

Lesions were produced in mice by the subcutaneous injection of cotton dust (1) alone, or impregnated (2) with $50 \mu 1$ of a 1 in 100 dilution of an overnight broth culture of staphylo-

Received 18 July 1968; accepted 22 Nov. 1968.

J. MED. MICROBIOL.-VOL. 2 (1969) 
cocci, equivalent to approximately $10^{5}$ colony forming units (c.f.u.) per dose (Noble), (3) with staphylococcal $\alpha$-lysin, or (4) with turpentine.

Organisms. Three strains of Staph. aureus were used to produce infection: strains PS80 (NCTC 9789) and Orbach, which will be referred to as virulent strains, gave rise to severe necropurulent lesions in mice; strain Wood 46 (NCTC 7121), which will be termed nonvirulent, caused insignificant lesions.

At appropriate times, the lesions were excised and ground up with sand, and the number of viable bacteria in them was determined. The counts given are those obtained from observations on groups of 3 mice.

Oedema was demonstrated by the blue zone that followed the intravenous injection of Evans blue. The degree of oedema was recorded in arbitrary units obtained by multiplying the lengths (in $\mathrm{mm}$ ) of the major and minor axes of the blue zones.

The severity of lesions was graded according to the scheme proposed by Noble:

$0=$ no reaction; complete absence of pus visible at the skin surface and no erythema except in the skin immediately above the cotton plug;

$1=$ slight reaction; minimal pus visible through the skin immediately above the plug and erythema in the skin around the plug;

$2=$ moderate reaction; an area of necrosis or a white zone not more than $5 \mathrm{~mm}$ in diameter; the white zones always progressed to necrosis within $24 \mathrm{hr}$;

$3=$ severe reaction; the zone of necrosis or white area greater than $5 \mathrm{~mm}$.

The lesions were examined at 24 and $48 \mathrm{hr}$ and the mean scores of groups of 6 mice were recorded as the 24 -hr score (maximum possible $=3$ ) or the cumulative 24 - and $48-\mathrm{hr}$ score (maximum possible $=6$ ).

Further details of the strains of staphylococci and the methods used were given by Agarwal (1967a).

\section{Mouse strains}

For most experiments, normal or immunised Swiss white mice were used. The complement-deficient mice were the B10 D2 " old line " strain (Rosenberg, 1965) lacking C'5. These were compared with B10 D2 " new line" mice, which are genetically identical with the "old line" except that they are not deficient in complement.

\section{Antilymphocyte serum}

An antiserum to mouse lymphocytes was prepared in rabbits by giving 2 subcutaneous injections of $10^{9}$ mouse spleen cells 2 wk apart. The rabbits were bled 1 wk later and the potency of the sera was tested by observing their lymphocytopenic effect in normal mice (Jeejeebhoy, 1965). If an effective serum had been produced, the rabbits were bled out and the sera were pooled and inactivated at $56^{\circ} \mathrm{C}$ for $30 \mathrm{~min}$. It proved necessary to absorb the sera overnight with mouse red cells to eliminate toxic reactions characterised by widespread haemorrhages and sometimes by death.

Mice were given $0.2 \mathrm{ml}$ of inactivated absorbed antilymphocyte serum by intraperitoneal injection 3 days and 1 day before the induction of a staphylococcal lesion. Control mice were given inactivated absorbed normal serum.

\section{Estimation of complement}

Mouse complement was titrated by the method of Rosenberg and Tachibana (1962).

\section{Immunisation of mice}

Swiss mice were immunised with 5 weekly subcutaneous injections each of $50 \mu \mathrm{g}$ of the residue left after extracting strain PS80 with deoxycholate (Hill, 1968). This imnunisation has been shown to inhibit lesion formation consequent upon the subcutaneous injection of strain PS80 and other virulent strains of Siaph. aureus together with cotton dust (Hill, 1969). 
Staphylococcal antibody. Agglutination titres were measured by adding $0.1 \mathrm{ml}$ of a suspension of washed staphylococci $\left(10^{9}\right.$ c.f.u. per $\left.\mathrm{ml}\right)$ from an overnight broth culture to $0 \cdot 1 \mathrm{ml}$ of doubling dilutions of mouse serum. The tubes were left $1 \mathrm{hr}$ at $37^{\circ} \mathrm{C}$ and then overnight in the refrigerator. The agglutination pattern was read macroscopically.

\section{RESULTS}

The effect of antilymphocyte serum on staphylococcal infection in normal and immune Swiss mice

Antilymphocyte serum did not alter the number of viable staphylococci found in experimental lesions produced in Swiss mice by $10^{5}$ c.f.u. of the virulent

\section{TABLE I}

Effect of antilymphocyte serum on lesions produced in Swiss mice by $10^{5}$ c.f.u. of the virulent Staphylococcus aureus strain Orbach

\begin{tabular}{c|c|c}
$\begin{array}{c}\text { Time after } \\
\text { injection of } \\
\text { staphylococci } \\
\text { (hr) }\end{array}$ & $\begin{array}{c}\text { Number of viable staphylococci per lesion } \\
\text { in mice given }\end{array}$ \\
& normal rabbit serum & antilymphocyte serum \\
\hline 0 & $8 \times 10^{4}$ & $8 \times 10^{4}$ \\
1 & $5 \times 10^{2}$ & $8 \times 10^{2}$ \\
2 & $3 \times 10^{3}$ & $7 \times 10^{2}$ \\
4 & $7 \times 10^{4}$ & $4 \times 10^{4}$ \\
7 & $2 \times 10^{6}$ & $4 \times 10^{6}$ \\
24 & & $2 \times 10^{8} \dagger$ \\
\hline
\end{tabular}

* Mean lesion score (MLS): $2 \cdot 4 ; \quad †$ MLS: $0 \cdot 6$.

TABLE II

Effect of antilymphocyte serum on lesions produced by $10^{5}$ and $10^{6}$ c.f.u. of Staphylococcus aureus strain PS80 in Swiss mice

\begin{tabular}{c|c|c}
\hline $\begin{array}{c}\text { Dose of PS80 } \\
\text { (c.f.u.) }\end{array}$ & $\begin{array}{c}\text { Mean lesion score at } 48 \mathrm{hr} \text { in Swiss mice } \\
\text { given }\end{array}$ \\
\hline 105 & normal rabbit serum & antilymphocyte serum \\
\hline 106 & 2.7 & 0.7 \\
\hline
\end{tabular}

strain Orbach, but the lesions at $24 \mathrm{hr}$ were much smaller in the treated than in the untreated mice, the lesion score being 0.6 compared with 2.4 (table I). Antilymphocyte serum also reduced the size of the lesions produced by $10^{5}$ c.f.u. of the virulent strain PS80. When the dose of PS80 was raised to $10^{6}$ c.f.u., however, the size of the lesion was not affected by antilymphocyte serum (table II). The non-virulent strain, Wood 46, which in normal mice did not 
give a count in the lesions of more than $10^{5}-10^{6}$ c.f.u. at $24 \mathrm{hr}$, showed after antilymphocyte serum a count as high as that usually found with virulent strains (table III). The lesions at $24 \mathrm{hr}$ remained small in both groups of mice. In normal mice, strain Wood 26 gave rise to marked local oedema at $4 \mathrm{hr}$, but this was largely suppressed by the antilymphocyte serum.

\section{TABLE III}

Effect of antilymphocyte serum on lesions produced in Swiss mice by the nonvirulent Staphylococcus aureus strain Wood 46

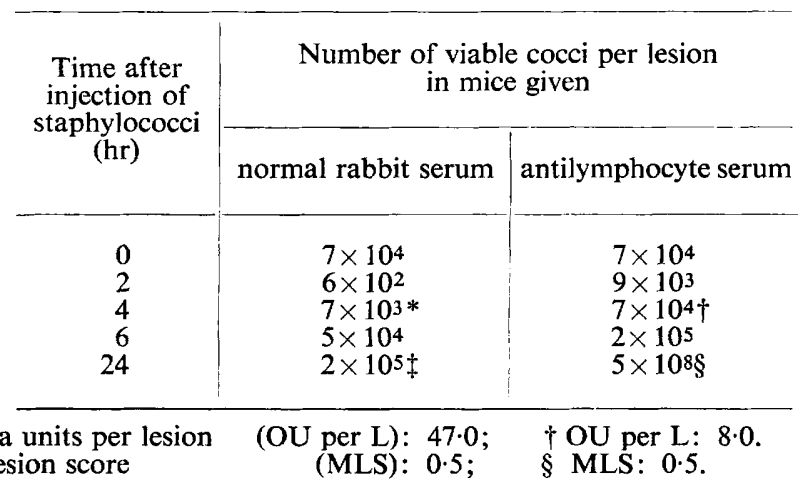

* Oedema units per
$\ddagger$ Mean lesion score (MLS): $0.5 ; \quad \S$ MLS: 0.5 .

\section{TABLE IV}

Effect of antilymphocyte serum on lesions produced in immunised Swiss mice by $3 \times 10^{5}$ c.f.u. of Staphylococcus aureus strain PS8O

\begin{tabular}{|c|c|c|c|}
\hline \multirow{2}{*}{$\begin{array}{c}\text { Time after } \\
\text { injection of } \\
\text { staphylococci } \\
\text { (hr) }\end{array}$} & \multicolumn{3}{|c|}{$\begin{array}{l}\text { Number of viable staphylococci per lesion } \\
\text { in mice }\end{array}$} \\
\hline & $\begin{array}{l}\text { given normal } \\
\text { rabbit serum }\end{array}$ & $\begin{array}{l}\text { immunised and given } \\
\text { normal rabbit serum }\end{array}$ & $\begin{array}{l}\text { immunised and given } \\
\text { antilymphocyte serum }\end{array}$ \\
\hline $\begin{array}{r}0 \\
2 \\
4 \\
6 \\
24\end{array}$ & $\begin{array}{l}3 \times 10^{5} \\
4 \times 10^{3} \\
8 \times 10^{4} * \\
2 \times 10^{6} \\
2 \times 10^{8} \S\end{array}$ & $\begin{array}{l}3 \times 10^{5} \\
8 \times 10^{2} \\
4 \times 10^{4} \dagger \\
4 \times 10^{5} \\
9 \times 10^{5} \|\end{array}$ & $\begin{array}{l}3 \times 10^{5} \\
1 \times 10^{3} \\
3 \times 10^{4}+ \\
4 \times 10^{4} \\
3 \times 10^{7} 9\end{array}$ \\
\hline
\end{tabular}

Mice immunised with a staphylococcal cell-wall fraction as described in Materials and methods were given subcutaneous injections of $3 \times 10^{5}$ c.f.u. of strain PS80 in cotton dust. There was marked oedema at $4 \mathrm{hr}$, and a low viable count, with no lesions at $24 \mathrm{hr}$. In immune mice previously treated with antilymphocyte serum, the oedema at $4 \mathrm{hr}$ was somewhat reduced, though not to the level observed in the unimmunised mice. The viable count at $24 \mathrm{hr}$ was higher in the immunised mice given antilymphocyte serum than in those given normal serum, but no lesions appeared (table IV). 
Since staphylococcal $\alpha$-lysin had been thought to play a significant part in lesion formation (Noble, 1965), graded doses of $\alpha$-lysin were given to mice treated with antilymphocyte serum and to normal controls. There was no difference in the lesions produced (table $\mathrm{V}$ ).

\section{TABLE V}

Effect of antilymphocyte serum on lesions formed by staphylococcal $\alpha-l y s i n$

\begin{tabular}{c|c|c}
\hline $\begin{array}{c}\text { Dose of staphylococcus } \\
\alpha \text {-lysin } \\
\text { (equivalent in units } \\
\alpha \text {-antitoxin) }\end{array}$ & \multicolumn{2}{|c}{ Mean lesion score at $48 \mathrm{hr}$ in mice given } \\
& normal rabbit serum & antilymphocyte serum \\
\hline 0 & $0 \cdot 6$ & \\
0.03 & $2 \cdot 0$ & $0 \cdot 6$ \\
0.06 & $3 \cdot 3$ & $2 \cdot 0$ \\
$0 \cdot 12$ & $4 \cdot 3$ & 3.0 \\
0.25 & $6 \cdot 0$ & $4 \cdot 3$ \\
0.5 & 6.0 & 6.7 \\
\hline
\end{tabular}

TABLE VI

Lesion formation in normal (B10 D2 " new"-line) and complement-deficient (B10 D2 "old"line) mice given different doses of staphylococcal strains PS80 and Wood 46

\begin{tabular}{|c|c|c|c|c|c|}
\hline \multicolumn{2}{|c|}{ Staphylococci } & \multicolumn{2}{|c|}{$\begin{array}{c}\text { Mean lesion score } \\
\text { at } 24 \mathrm{hr} \text { in }\end{array}$} & \multicolumn{2}{|c|}{$\begin{array}{c}\text { Mean Iesion score } \\
\text { at } 48 \mathrm{hr} \text { in }\end{array}$} \\
\hline $\begin{array}{l}\text { Strain } \\
\text { no. }\end{array}$ & $\begin{array}{l}\text { Number } \\
\text { injected }\end{array}$ & $\begin{array}{l}\text { normal } \\
\text { mice }\end{array}$ & $\begin{array}{l}C^{\prime} 5- \\
\text { deficient } \\
\text { mice }\end{array}$ & $\begin{array}{c}\text { normal } \\
\text { mice }\end{array}$ & $\begin{array}{c}C^{\prime} 5- \\
\text { deficient } \\
\text { mice }\end{array}$ \\
\hline $\begin{array}{l}\text { PS80 } \\
\text { PS80 } \\
\text { PS80 } \\
\text { PS80 }\end{array}$ & $\begin{array}{l}10^{4} \\
105 \\
10^{6} \\
10^{7}\end{array}$ & $\begin{array}{l}0 \\
1 \cdot 1 \\
1 \cdot 1 \\
1 \cdot 3\end{array}$ & $\begin{array}{l}0 \cdot 3 \\
1 \cdot 7 \\
1 \cdot 7 \\
2 \cdot 5\end{array}$ & $\begin{array}{l}0 \cdot 5 \\
3 \cdot 3 \\
3 \cdot 0 \\
3 \cdot 8\end{array}$ & $\begin{array}{l}1.0 \\
3.3 \\
3.6 \\
5.4\end{array}$ \\
\hline $\begin{array}{l}\text { Wood } 46 \\
\text { Wood } 46 \\
\text { Wood } 46 \\
\text { Wood } 46\end{array}$ & $\begin{array}{l}10^{4} \\
10^{5} \\
10^{6} \\
10^{7}\end{array}$ & $\begin{array}{l}1 \cdot 0 \\
0 \cdot 6 \\
1 \cdot 5 \\
1 \cdot 3\end{array}$ & $\begin{array}{l}0.8 \\
1.0 \\
1.3 \\
0.8\end{array}$ & $\begin{array}{l}1 \cdot 8 \\
1 \cdot 3 \\
3 \cdot 0 \\
2 \cdot 4\end{array}$ & $\begin{array}{l}0 \cdot 8 \\
2 \cdot 0 \\
3 \cdot 2 \\
3 \cdot 0\end{array}$ \\
\hline
\end{tabular}

\section{Staphylococcal lesions in $C^{\prime} 5$-deficient mice}

The essential comparison to be made was between the normal B10 D2 "new"line mice and the C'5-deficient B10 D2 "old"-line mice. As it seemed likely that even the normal "new"-line mice would not necessarily react in exactly the same way or to the same degree as the Swiss mice, preliminary experiments were done recording the lesion score after graded doses of the staphylococcal strains PS80 and Wood 46 (table VI). 
In the "old "- and " new"-line mice the differences between the lesions produced by PS 80 and those produced by Wood 46 were much less than had been found in the Swiss mice.

Comparison of the "old"- and "new"-line strains showed no systematic differences in the lesions due to Wood 46. When given PS80 the "old "line,

\section{TABLE VII}

Acute inflammatory response to $10^{6}$ c.f.u. of staphylococcal strains PS80 and Wood 46 in normal (B1O D2 "new"-line) and in complement-deficient (B1O D2"old"-line) mice

\begin{tabular}{l|c|c|c}
$\begin{array}{c}\text { Strain } \\
\text { of } \\
\text { staphylococcus }\end{array}$ & $\begin{array}{c}\text { Time } \\
\text { after } \\
\text { injection } \\
\text { (hr) }\end{array}$ & $\begin{array}{c}\text { Mormal } \\
\text { mice }\end{array}$ & $\begin{array}{c}\text { C'5- } \\
\text { deficient mice }\end{array}$ \\
\hline PS80 & 2 & 28 & 4 \\
PS80 & 4 & 129 & 47 \\
PS80 & 6 & 122 & 100 \\
Wood 46 & 2 & 7 & 4 \\
Wood 46 & 4 & 54 & 9 \\
Wood 46 & 6 & Very large & \\
\hline
\end{tabular}

\section{TABLE VIII}

Bacterial count in lesions produced by $10^{6}$ c.f.u. of strain PS80 in normal (B1O D2 " new"-line) and complement-deficient (B10 D2 "old"-line) mice

\begin{tabular}{|c|c|c|}
\hline \multirow{2}{*}{$\begin{array}{c}\text { Time } \\
\text { after injection } \\
\text { (hr) }\end{array}$} & \multicolumn{2}{|c|}{ Number of viable staphylococci per lesion in } \\
\hline & $\begin{array}{c}\text { normal } \\
\text { mice }\end{array}$ & $\begin{array}{c}C^{\prime} 5 \text {-deficient } \\
\text { mice }\end{array}$ \\
\hline $\begin{array}{r}0 \\
2 \\
4 \\
6 \\
24\end{array}$ & $\begin{array}{l}4 \times 10^{6} \\
1 \times 10^{3} \\
6 \times 10^{4} \\
3 \times 10^{5} \\
1 \times 10^{7}\end{array}$ & $\begin{array}{l}4 \times 10^{6} \\
2 \times 10^{4} \\
1 \times 10^{7} \\
3 \times 10^{7} \\
3 \times 10^{8}\end{array}$ \\
\hline
\end{tabular}

i.e., complement-deficient mice, developed larger lesions at $24 \mathrm{hr}$ than did the normal mice. The difference was most marked with a dose of $10^{7}$ c.f.u. of PS80. At $48 \mathrm{hr}$ the difference persisted with this dose and with $10^{6}$ c.f.u., but was not apparent with doses of $10^{4}$ and $10^{5}$ c.f.u.

Early oedema formation and the number of viable bacteria per lesion were then examined after injection of $10^{6}$ c.f.u. of PS80 and Wood 46. Again, the difference between PS80 and Wood 46 found by Agarwal (1967b) in Swiss mice was no longer evident (table VII). However, with both strains of staphylococcus, oedema was always greater in the normal than in the complement-deficient 
mice. With PS80 the bacterial count from $2 \mathrm{hr}$ to $24 \mathrm{hr}$ was larger in the complement-deficient than in the normal mice (table VIII). Bacterial counts were not done with Wood 46.

\section{Antilymphocyte serum in B10 D2 "old"- and "new"-line mice}

When B10 D2 mice were given antilymphocyte serum followed by PS80, the results were similar in both normal and $\mathrm{C}^{\prime} 5$-deficient strains, and, like the results in the Swiss mice (table II), depended on the number of staphylococci given. When staphylococcus PS80 was given in a dose of $10^{5}$ c.f.u., antilymphocyte serum suppressed the lesions. When the dose of staphylococci was increased to $10^{6}$ c.f.u., antilymphocyte serum was associated with larger lesions (table IX). In this particular experiment there was no difference in the lesions

\section{TABLE IX}

Lesion scores produced by $10^{5}$ and $10^{6}$ c.f.u. of strain PS80 in normal (B10 D2 "new"-line) and complement-deficient (B10 D2 "old"-line) mice previously treated with antilymphocyte serum

\begin{tabular}{|c|c|c|c|c|c|}
\hline \multirow{2}{*}{$\begin{array}{l}\text { Strain of } \\
\text { mouse }\end{array}$} & \multirow{2}{*}{$\begin{array}{l}\text { Dose of } \\
\text { staphylococcus } \\
\text { (c.f.u.) }\end{array}$} & \multicolumn{2}{|c|}{$\begin{array}{c}\text { Mean lesion score } \\
\text { at } 24 \mathrm{hr} \\
\text { in mice given }\end{array}$} & \multicolumn{2}{|c|}{$\begin{array}{c}\text { Mean lesion score } \\
\text { at } 48 \mathrm{hr} \\
\text { in mice given }\end{array}$} \\
\hline & & $\begin{array}{l}\text { normal } \\
\text { rabbit } \\
\text { serum }\end{array}$ & $\begin{array}{l}\text { antilymphocyte } \\
\text { serum }\end{array}$ & $\begin{array}{c}\text { normal } \\
\text { rabbit } \\
\text { serum }\end{array}$ & $\begin{array}{l}\text { antilymphocyte } \\
\text { serum }\end{array}$ \\
\hline $\begin{array}{l}\text { Normal } \\
\text { Normal }\end{array}$ & $\begin{array}{l}105 \\
106\end{array}$ & $\begin{array}{l}1.3 \\
0.7\end{array}$ & $\begin{array}{l}0.5 \\
1.3\end{array}$ & $\begin{array}{c}2 \cdot 6 \\
\ldots\end{array}$ & $\begin{array}{c}0.8 \\
\ldots\end{array}$ \\
\hline $\mathrm{C}^{\prime} 5-$ & 105 & $1 \cdot 3$ & 0.5 & $2 \cdot 8$ & 0.5 \\
\hline $\begin{array}{l}\text { deficient } \\
C^{\prime} 5- \\
\text { deficient }\end{array}$ & 106 & $1 \cdot 7$ & 3.0 & $\ldots$ & $\cdots$ \\
\hline
\end{tabular}

$\ldots=$ Not recorded.

produced in normal and $\mathrm{C}^{\prime} 5$-deficient mice given $10^{5}$ c.f.u. PS80 and normal rabbit serum.

The bacterial counts at $24 \mathrm{hr}$ in the lesions of both strains of mice given $10^{5}$ c.f.u. PS 80 were greater after antilymphocyte serum than after normal rabbit serum (table X). However, unlike the findings in a previous experiment (table VIII) the counts at $24 \mathrm{hr}$ in the controls given normal rabbit serum were not greater in the complement-deficient mice than in the normal mice. In the groups given antilymphocyte serum, the $\mathrm{C}^{\prime} 5$-deficient mice had larger bacterial counts at $24 \mathrm{hr}$ than did the normal mice.

Thus, in a straightforward comparison (tables VI and VIII) of normal and $\mathrm{C}^{\prime} 5$-deficient mice, the latter had larger lesions containing more bacteria at $24 \mathrm{hr}$. This difference was not present when control groups of normal and $\mathrm{C}^{\prime} 5$ deficient mice were compared in the experiments using antilymphocyte serum 
(tables IX and X). A possible explanation for this discrepancy is that the control groups in the experiments with antilymphocyte serum received normal rabbit serum, whilst the mice referred to in tables VI and VIII did not. Although the normal rabbit serum had been heated to destroy $C^{\prime} 5$, it may still have provided sufficient extra amounts of the heat-stable components of complement and of staphylococcal antibodies to enable the mice lacking $C^{\prime} 5$ to overcome their deficiency.

\section{Spread of infection with antilymphocyte serum}

Swiss mice, both normal and treated with antilymphocyte serum, were given an injection of $10^{5}$ c.f.u. PS80 on cotton dust into the subcutaneous tissue. Quantitative cultures of staphylococci were made on $0.05-\mathrm{ml}$ blood samples at

TABLE X

Bacterial counts in lesions produced by $10^{6}$ c.f.u. of strain PS80 in normal (B10 D2a "new"-line and complement-deficient (B10 D2 "old"-line) mice previously treated with ntilymphocyte) serum

\begin{tabular}{|c|c|c|c|c|}
\hline \multirow{3}{*}{$\begin{array}{l}\text { Time } \\
\text { after injection } \\
\text { (hr) }\end{array}$} & \multicolumn{4}{|c|}{ Number of viable staphylococci per lesion in } \\
\hline & \multicolumn{2}{|c|}{ normal mice given } & \multicolumn{2}{|c|}{$C^{\prime} 5$-deficient mice given } \\
\hline & $\begin{array}{l}\text { normal rabbit } \\
\text { serum }\end{array}$ & $\begin{array}{l}\text { antilymphocyte } \\
\text { serum }\end{array}$ & $\begin{array}{c}\text { normal rabbit } \\
\text { serum }\end{array}$ & $\begin{array}{l}\text { antilymphocyte } \\
\text { serum }\end{array}$ \\
\hline $\begin{array}{r}0 \\
2 \\
3 \\
4 \\
6 \\
24\end{array}$ & $\begin{array}{c}1 \times 10^{6} \\
2 \times 10^{3} \\
\cdots \\
2 \times 10^{4} \\
3 \times 10^{6} \\
5 \times 10^{7}\end{array}$ & $\begin{array}{c}1 \times 10^{6} \\
1 \times 10^{4} \\
\cdots \\
3 \times 10^{6} \\
6 \times 10^{6} \\
4 \times 10^{8}\end{array}$ & $\begin{array}{c}1 \times 10^{6} \\
\ldots \times 10^{4} \\
\cdots \\
4 \times 10^{2} \\
3 \times 10^{7}\end{array}$ & $\begin{array}{c}1 \times 10^{6} \\
\cdots \\
2 \times 10^{5} \\
\cdots \\
6 \times 10^{8} \\
9 \times 10^{8}\end{array}$ \\
\hline
\end{tabular}

$1,2,4,6,24$ and $48 \mathrm{hr}$, and on liver, spleen, lungs and kidneys at 6, 24 and $48 \mathrm{hr}$ after the injection. Counts of 20-200 staphylococci per $\mathrm{ml}$ were found in some blood samples at $2 \mathrm{hr}$, but none was found later. Some mice had 1-6 staphylococci in the liver or spleen at $6 \mathrm{hr}$, but none at any other time. There was no difference between the treated and control mice.

\section{Antilymphocyte serum and inflammation not due to bacteria}

Antilymphocyte serum reduced the oedema response to cotton dust. As has already been found by Willoughby and Spector (1968), antilymphocyte serum also reduced the oedema response to subcutaneous injection of turpentine (table XI).

\section{Staphylococcal agglutination titres in normal mice}

Serum samples from 12 normal Swiss mice were tested against suspensions of PS80 and Wood 46. Agglutination titres were high, ranging from 80 to 640 for PS80 and from 640 to 1280 for Wood 46. 


\section{Discussion}

The protective value of inflammation against a local bacterial infection has been demonstrated by Miles, Miles and Burke (1957). Agarwal (1967b) suggested that one characteristic of virulent staphylococci was their ability to inhibit the early inflammatory response. Our findings with antilymphocyte serum fit in with these concepts, in that the suppression of inflammation by the serum was often associated with a more numerous bacterial population at $24 \mathrm{hr}$. This was observed, for example, with the non-virulent strain Wood 46, but not with the virulent strain Orbach in normal Swiss mice, and with the virulent strain PS80 in immunised Swiss mice and in unimmunised B10 D2 mice whether or not they were complement-deficient.

TABLE XI

Effect of antilymphocyte serum on inflammation produced in Swiss mice by the intradermal injection of cotton dust with or without turpentine

\begin{tabular}{l|c|c}
\hline \multirow{2}{*}{ Irritant material } & \multicolumn{2}{|c|}{ Mean zone size of oedema (units) in mice given } \\
\cline { 2 - 3 } & normal rabbit serum & antilymphocyte serum \\
\hline Cotton dust & & \\
(4-hr readings) & 30 & 4 \\
& 27 & 4 \\
& 25 & 4 \\
\hline Cotton dust and & 53 & \\
turpentine read & & \\
at $1 \mathrm{hr}$ & & 31 \\
$2 \mathrm{hr}$ & 117 & 59 \\
$3 \mathrm{hr}$ & 137 & 125 \\
\hline
\end{tabular}

The effect of antilymphocyte serum on the severity of the lesion was variable, and depended on the initial dose of the organism, on the strain of staphylococcus, and on the variety of mice used. There is presumably a conflict between the effect of increased bacterial multiplication and the continuing anti-inflammatory effect of the antilymphocyte serum. Thus lesions produced by $10^{5}$ c.f.u. of PS80 were suppressed by antilymphocyte serum, whereas lesions produced by $10^{6}$ c.f.u. were not. The normally avirulent but in vitro very toxigenic strain Wood 46 failed to produce a significant lesion even when very large numbers of bacteria had grown in the tissues. Evidence that Wood 46 does produce $\alpha$-toxin in vivo is given by the observation that a large inoculum causes some erythema which can be specifically inhibited by antitoxin. More severe lesions were seen after treatment with antilymphocyte serum in B10 D2 mice, whether normal or complement-deficient, given large doses of strain PS80.

Antilymphocyte serum has also been shown to reduce the size of induced 
intradermal staphylococcal lesions by Morris, Bondoc and Burke (1966), who measured the area of induration produced at $24 \mathrm{hr}$, but did not count the bacteria in the lesions.

The finding that in the B10 D2 mice the staphylococcal strains PS80 and Wood 46 produced lesions of similar size was unexpected (table VI). The real difference between the B10 D2 and the Swiss mice was a reduction in size of the lesions due to PS80 in the former. However, this is still in accord with the views on the role of early inflammation discussed above, since, in the B10 D2 mice, PS80 produced as much early oedema as did Wood 46 (table VII).

The suppression by antilymphocyte serum of the response to turpentine suggests at first sight a non-specific anti-inflammatory action with no immunological basis. It is unlikely that antilymphocyte serum has any direct action on turpentine or even on any subsequent chemical mediators of inflammation. However, it is possible that lymphocytes are normally involved in any inflammatory process, so providing a susceptible step in the chain of events that follows the injection of turpentine. Antilymphocyte sera are poorly defined and may also include anti-lymph-node-permeability-factor (Turk and Willoughby, 1967) which might be important in acute inflammation.

None of this excludes the possibility of additional, more specific, effects. As long ago as 1929 Panton and Valentine suggested that hypersensitivity played a part in staphylococcal skin infections, and, evidence of delayed-type hypersensitivity was presented by Johanovsky (1958) and by Johnson, Cluff and Goshi (1961). Martin, Daugharty and White (1965) demonstrated hypersensitivity, possibly of the Arthus type, to staphylococcal teichoic acids in man.

If there are immunological mechanisms underlying the early inflammation due to staphylococci, it may not be profitable to speculate on their nature here, but it is reasonable to suppose that antilymphocyte serum could interfere with them. Antilymphocyte serum has been shown to suppress delayed hypersensitivity and, in some systems at least, to interfere with primary and even secondary antibody responses. There is a little evidence that it does not affect the Arthus reaction (James, 1967). Whatever the immunological mechanism concerned, it must in the experiments described here have come into action within an hour or two of the staphylococcal challenge. This seems a short time for the formation of a conventional circulating antibody, but might be sufficient for the local action of lymphocytes already committed by previous experience of staphylococci. If circulating antibody were involved, even if production had stopped, less than 32 per cent. of the antibody already present would disappear in the 3 days separating the first dose of antilymphocyte serum from the injection of staphylococci. The half life of IgG in normal mice is 5.4 days (Sell and Fahey, 1964), but breakdown of IgG slows as the blood level falls.

In our experiments, injections of antilymphocyte serum had no effect on the level of circulating complement in mice.

It may also be significant that Knight et al. (1965) were able to cause nonspecific blast transformation of mouse lymphocytes in vitro by treating them with staphylococcal filtrates.

Evidence that the mice used in the present work may have had previous 
experience of staphylococci is provided by the agglutinin titres found. The high titres given by well clotted serum make it likely that these were true agglutinations rather than clumping due to bound coagulase. Similar widespread antibodies to staphylococci were found in mice by Cohen et al. (1963), who used gel precipitation with purified antigen, a technique that precludes clumping. With sera from adult conventional mice two or more precipitin lines were usually produced. Although one line from each mouse serum tested was due to protein A combining with mouse gamma-globulin, the other lines were presumably due to true antigen-antibody reactions. In addition, the combination of protein A with the Fc part of the gamma-globulin molecule can itself lead to Arthus-like reactions, presumably due to fixation of complement by the aggregated distorted gamma-globulin (Gustafson, Sjöquist and Stålenheim, 1967).

In view of the scarcity of evidence that complement has a significant defensive role in vivo (Rosenberg, 1965; Glynn and Medhurst, 1967) it is interesting that the complement-deficient mice had larger lesions than the normal. There is as yet no evidence as to which of several possible mechanisms is involved. Complement has no direct lethal action on staphylococci, and opsonisation can proceed normally in the absence of $\mathrm{C}^{\prime} 5$ (Stiffel et al., 1964; Glynn and Medhurst). However, Shayegani and Mudd (1966) have suggested that complement augments intracellular killing of staphylococci. It is more likely that the larger lesions in the complement-deficient mice are due to the smaller early inflammatory response. Possibly the absence of $\mathrm{C}^{\prime} 5$ leads to inadequate chemotaxis (Ward, Cochrane and Müller-Eberhard, 1966) and so prevents the development of an Arthus reaction. Rother, Rother and Schindera (1964) and Biro (1966) found that the Arthus reaction was impaired in rabbits deficient in $C^{\prime} 6$. If $C^{\prime} 6$ is necessary it is to be expected that $C^{\prime} 5$ would also be required.

It is of theoretical interest that, at least in the model infection used here, the suppression of inflammation often led to increased bacterial multiplication, but apparently did not lead to spread of staphylococci to the blood, or to their establishment elsewhere in the body. Moreover, the original lesion remained self-limiting. It would be dangerous to transfer these findings uncritically to man. Experience with cortisone has shown the risks of suppressing inflammation both in subsequent severity of infection and in delay in diagnosis.

\section{SUMMARY}

The effect of antilymphocyte serum on subcutaneous staphylococcal lesions in normal, immune and $\mathrm{C}^{\prime} 5$-deficient mice was studied. In general, the inflammatory response at $4 \mathrm{hr}$ was suppressed or reduced, and the 24-hr count of non-virulent bacteria rose to the level normally reached by virulent strains, but no lesion developed. The effect of antilymphocyte serum on the severity of lesions due to virulent strains depended on the size of the inoculum, the strain of staphylococcus and the variety of mice used. The treatment of B10 D2 mice, whether normal or complement-deficient, with antilymphocyte serum increased the severity of the lesion. 
Antilymphocyte serum had no effect on the action of $\alpha$-lysin, but reduced the inflammatory response to cotton dust and to turpentine.

Immunised mice treated with antilymphocyte serum behaved more like unimmunised mice, but did not develop lesions.

When large doses of PS80 were administered, the complement-deficient strains of B10 D2 mice produced smaller early inflammatory responses, and developed bigger lesions containing more bacteria, than did normal B10 D2 mice.

The results are discussed in relation to the mode of action of antilymphocyte serum, the pathogenesis of staphylococcal lesions and the defensive role of complement.

One of us (F. A. M.) is the holder of a Research Fellowship from the Sir Halley Stewart Trust; M. J. H. is in receipt of a grant from the Medical Research Council.

We thank the Smith Kline and French Foundation for a grant for expenses in connexion with complement-deficient mice.

\section{REFERENCES}

Agarwal, D. S.

Biro, C." E.

Cohen, J. O., Newton, W. L., Cherry, W. B., AND UPDYKe, ElAINE L.

Glynn, A. A., AND Medhurst, Fiona A.

Gustafson, G. T., SJöQUist, J., AND STÅLENHEIM, G.

HiLl, M. J.

JAMES, K. .

JEEJEEBHOY, H. F.

JOHANOVSKY, J.

Johnson, J. E., Cluff, L. E., AND GoshI, $\mathrm{K}$.

Kashiwagi, N., Brantigan, C. O., BretTSCHNEIDER, L., Groth, C. G., AND STARZL, T. E.

Knight, Stella, Ling, N. R., Sell, S., AND OXNARD, C. E.

Martin, R. R., DaUgharty, H., AND WhITE, $A$.

Miles, A. A., Miles, Ellen M., ANd BURKE, J.

Morris, P. J., Bondoc, C., AND Burke, J. F.

Noble, W. C.

Panton, P. N., and Valentine, F. C. O.

ROSENBERG, L. T

RosenberG, L. T., AND TAChIBANA, DORA K.

ROTHER, K., ROTHER, URSULA, AND SCHINDERA, F. 1967a. Br. J. Exp. Path., 48, 436.

1967b. Ibid., 48, 468.

1967c. Ibid., 48, 483.

1966. Immunology, 10, 563 .

1963. J. Immun., 90, 358.

1967. Nature, Lond., 213, 608.

1967. J. Immun., 98, 1178.

1968. J. Med. Microbiol., 1, 33.

1969. Ibid., $2,1$.

1967. Clin. Exp. Immun., 2, 615.

1965. Immunology, 9, 417.

1958. Nature, Lond., 182, 1454.

1961. J. Exp. Med., 113, 235.

1968. Ann. Intern. Med., 68, 275.

1965. Immunology, 9, 565.

1965. Antimicrob. Ag. Chemother., p. 91.

1957. Br. J. Exp. Path., 38, 79.

1966. Surg. Forum, 17, 74.

1965. Br. J. Exp. Path., 46, 254.

1929. Ibid., 10, 257.

1965. A. Rev. Microbiol., 19, 285.

1962. J. Immun., 89, 861.

1964. Z. ImmunForsch. AllergieForsch., 126, 473. 
Sell, S., AND Fahey, J. L. - $\quad$ - $\quad$ - 1964. J. Immun., 93, 81.

ShaYegan, M. G., AND Mudd, S. 1966. J. Bact., 91, 1393.

Stiffel, C., Biozzi, G., Mouton, D., 1964. J. Immun., 93, 246.

Bouthillier, Y., AND DeCreusefond,

C.

TURK, J. L., AND WilloughBy, D. A. . 1967. Lancet, 1, 249.

Ward, P. A., Cochrane, C. G., AND 1966. Immunology, 11, 141.

MÜLLER-EBERHARD, H. J.

Willoughby, D. A., ANd Spector, W. G. 1968. Biochem. Pharmac., 17, Suppl., p. 123. 